Jurnal Riset Agama

Volume 1, Nomor 1 (April 2021): 1-14

https://journal.uinsgd.ac.id/index.php/jra

\title{
Habbatussauda dalam Peningkatan Imun di Masa Covid-19
}

\author{
Muhamad Ikhsan \\ Jurusan Ilmu Al-Qur'an dan Tafsir, Fakultas Ushuluddin \\ UIN Sunan Gunung Djati Bandung \\ muhamadicun20@gmail.com
}

\begin{abstract}
The purpose of this study is to discuss the hadith of Black Seed as an alternative in increasing immunity during the Covid-19 period. This research uses a qualitative approach through literature study by applying the method of takhrij hadith and syarah hadith. The interpretation is used to analyze contemporary issues. The results of the research and discussion show that the hadith about Black Seed as one of the authentic quality herbal treatments according to takhrij reviews so that it can be practiced as an Islamic argument. While the syarah of this hadith shows that Black Seed is used for the treatment of various diseases, moreover it is very useful for increasing one's body immunity, however this Black Seed also cannot absolutely be interpreted to treat all diseases, especially Covid-19, further research is needed on this matter. The conclusion of this study is that the hadith about Black Seed is maqbul for herbal treatment, but with the right rules and doses and it is even better if it is under the supervision of the relevant experts, namely health experts.
\end{abstract}

Keywords: Covid-19, Black Seed, Hadith, Medicine

\begin{abstract}
Abstrak
Tujuan penelitian ini yaitu membahas hadits habbatussauda sebagai salah satu alternatif dalam meningkatkan imun pada masa Covid-19. Penelitian ini menggunakan pendekatan kualitatif melalui studi pustaka dengan menerapkan metode takhrij hadits dan syarah hadits Adapun interpretasi digunakan analisis isu kontemporer. Hasil penelitian dan pembahasan menunjukan bahwa hadits tentang habbatussauda sebagai salah satu pengobatan herbal berkualitas shahih menurut tinjauan takhrij sehingga dapat diamalkan sebagai dalil Islam. Sedangkan syarah hadits ini menunjukan bahwa habbatussauda digunakan untuk pengobatan berbagai penyakit terlebih lagi sangat bermanfaat untuk meningkatkan
\end{abstract}


Jurnal Riset Agama, Volume 1, Nomor 1 (April 2021): 1-14

Muhamad Ikhsan/Habbatussauda dalam Peningkatan Imun di Masa Covid-19

imunitas tubuh seseorang, namun demikian habbatussauda ini juga tidak bisa secara mutlak dimaknai mengobati keseluruhan penyakit terlebih lagi Covid-19, dibutuhkan penelitian lebih lanjut mengenai hal tersebut. Kesimpulan dari penelitian ini ialah bahwa hadits tentang habbatussauda maqbul bagi pengobatan herbal, namun dengan aturan dan dosis yang tepat serta lebih baik lagi jika dalam pengawasan orang ahli yang terkait, yakni ahli kesehatan.

Kata Kunci: Covid-19, Habbatussauda, Hadits, Obat

\section{Pendahuluan}

Habbatussauda oleh masyarakat Indonesia dipahami sebagai obat dari segala penyakit berdasarkan hadits (Halim et al., 2020). Namun, disebutkan Ibn Hajar al-Asqalani dalam Kitab Fathul Bari, Syarah Shahih Bukhari bahwa Imam al-Khattabi menerangkan ungkapan "penawar segala penyakit" merupakan lafaz umum yang membawa maksud yang khusus (Halim et al., 2020). Penggunaan maksud yang khusus adalah tepat karena menurut Imam al-Khattabi tidak ada satu pun tumbuhan yang diciptakan oleh Allah Swt. di dunia ini yang terkumpul di dalamnya semua manfaat bagi tujuan pengobatan (Halim et al., 2020). Serta juga belum ada penelitian yang mengklaim dengan jelas bahwa habbatussauda merupakan obat Covid-19, melainkan secara keseluruhan membantu fungsi hati dalam mengelola zat toksik dalam tubuh (Arofi, 2021). Pernyataan antara dunia medis dan hadits tersebut secara tekstual seakan bertabrakan, oleh karena itu penulis ingin melakukan penyelesaian menggunakan teori ilmu hadits berikut syarahnya melalui pendekatan ilmu kesehatan.

Sejumlah ahli telah melakukan penelitian tentang habbatussauda terkait dengan pandemi Covid-19 sebagaimana dalam tinjauan pustaka ini. Antara lain Abdul, Halim, Amran, et al. (2020), “Wabah Covid-19 dan Hubungannya dengan Hadith Kelebihan Habbatus Sauda'," Universiti Sains Islam Malaysia. Penelitian ini membahas tentang anjuran dari pemerintah Malaysia yang berisikan untuk melakukan social distancing serta juga dengan membahas hadits yang berkenaan bahwa habbatussauda dapat menyembuhkan segala macam penyakit. Penelitian ini termasuk ke dalam jenis penelitian kualitatif dengan pendekatan analisis kritis. Penelitian ini menyimpulkan bahwa peraturan Pemerintah Malaysia terkait social distancing pada masa pandemi Covid-19 tidak bertentangan dengan ajaran Rasulullah serta juga pembahasan bahwa habbatussauda tidak dapat serta merta menyembuhkan Covid-19 (Halim et al., 
Jurnal Riset Agama, Volume 1, Nomor 1 (April 2021): 1-14

Muhamad Ikhsan/Habbatussauda dalam Peningkatan Imun di Masa Covid-19

2020). Arofi, Zuhron (2021), “Optimis di Tengah Pandemi: Cara Rasulullah Menyelesaikan Pandemi," Lembaga Pembinaan dan Pengembangan Studi Islam Universitas Muhammadiyah Magelang. Penelitian ini membahas tentang cara Rasulullah dalam menyelesaikan wabah penyakit yang ditinjau melalui hadits-hadits Rasulullah. Penelitian ini menggunakan metode kualitatif dengan pendekatan syarah hadits. Kesimpulan dari penelitian ini adalah bahwa dalam menyelesaikan wabah Covid-19 dapat ditiru dari bagaimana di zaman Nabi juga telah ada dan dengan cara-cara yang telah disebutkan dalam Al-Qur'an dan Al-Hadits untuk melakukan isolasi mandiri memakan kurma, habbatussauda, madu, dan sejenisnya, serta berharap kesembuhan hanya dari Allah (Arofi, 2021). Dalil, F.Y. (2016), "Hadis-hadis tentang Farmasi: Sebuah Kajian Intergratif dalam Memahami Hadis Rasulullah," International Conference IAIN Batusangkar. Penelitian ini menggunakan teori kesehatan masyarakat yang objeknya adalah berasal dari hadits-hadits Rasulullah yang merupakan jenis penelitian kualitatif dengan pendekatan studi integratif. Kesimpulan pada penelitian ini adalah bahwa hadits-hadits Rasulullah cukup berkontribusi pada dunia kesehatan khususnya dalam bidang farmakologi (M.Dalil, 2017).

Penilitian terdahulu yang telah diulas pada tinjauan pustaka berkontribusi terhadap penyusunan kerangka berpikir ini. Mulai akhir tahun 2019 dunia internasional dihebohkan dengan munculnya penyakit yang dikenal dengan Covid-19 yang nama virusnya yaitu SARS-Cov-2 (Yuliana, 2020), tidak disangka yang mulanya hanya terjadi di Wuhan, Cina, dalam hitungan bulan dapat menyebar dengan cepat menjangkau ke setiap belahan dunia termasuk Indonesia. Upaya untuk memutus rantai penularan penyakit yang disebabkan oleh virus ini adalah dengan menghindari kontak dengan cara mempraktikkan social dan physical distancing dan meningkatkan kebersihan diri, serta meningkatkan imunitas atau pertahanan tubuh terhadap virus SARS-Cov-2 ini (Sumarmi, 2020). Seluruh umat Islam telah menerima paham, bahwa hadits Rasulullah Saw. itu sebagai pedoman hidup yang utama setelah Al-Qur'an (Rahman, 1974). Demikian pengertian hadits secara umum dibatasi sebagai segala perkataan, perbuatan, dan taqrir setelah kenabian (S. Puyu, 2012). Takhrij ialah menunjukkan atau mengemukakan letak asal hadits para sumbernya yang asli, yakni berbagai kitab, yang di dalamnya dikemukakan hadits itu secara lengkap dengan sanadnya masing-masing; kemudian, untuk kepentingan penelitian, dijelaskan kualitas hadits yang bersangkutan (S. Puyu, 2012). Berdasarkan penelusuran dengan kata "habbatussauda" ditemukanlah hadits yang terkait (yang menyebutkan habbatussauda) berjumlah delapan belas hadits, akan tetapi yang penulis akan 
Jurnal Riset Agama, Volume 1, Nomor 1 (April 2021): 1-14

Muhamad Ikhsan/Habbatussauda dalam Peningkatan Imun di Masa Covid-19

bahas pada penelitian ini hanyalah hadits riwayat Imam al-Bukhari No. 5255 Kitab Pengobatan Bab Habbatussauda dan pada versi Fathul Bari' No. 5687 (Saltanera, 2015). Seperti yang disebutkan oleh Subhi al-Shalih, kitab Shahih al-Bukhari dan Shahih Muslim adalah kitab yang paling shahih setelah AlQur'an (Bakar Adanan, 2020), setelah status hadits tersebut diketahui kemudian dilakukan syarah untuk menjelaskan makna yang terkandung teks hadits (Darmalaksana, 2021a), maka dari itu penelitian ini akan membahas "hadits habbatussauda" dengan cara mentakhrij dan melakukan syarah menggunakan pendekatan ilmu yang sejalan dan relevan dengannya. Habbatussauda adalah sejenis tumbuh-tumbuhan dikenal dengan nama "Jintan Hitam," jenis tanaman ini memiliki khasiat yang sangat ampuh untuk mengatasi berbagai masalah kesehatan dan kecantikan (M.Dalil, 2017). Seperti yang disabdakan oleh Nabi Saw. dalam hadits yaitu "gunakanlah habbatussauda karena di dalamnya terdapat sejenis obat yang menyembuhkan pelbagai penyakit kecuali mati," dan juga membantu memperkuat sistem imun (Halim et al., 2020). Meskipun banyak manfaatnya, masyarakat awam tidak boleh mengambil kefahaman bahwa habbatussauda adalah obat untuk segala macam penyakit di dunia ini secara literal karena itu adalah pemahaman yang tidak tepat (Halim et al., 2020).

Berdasarkan paparan di atas, penulis berusaha menyusun formula penelitian, yaitu rumusan masalah, pertanyaan utama penelitian, dan tujuan penelitian (Darmalaksana, 2020a). Rumusan masalah penelitian ini adalah terdapat syarah hadits tentang habbatussauda dalam peningkatan imun di masa Covid-19. Pertanyaan utama penelitian ini ialah bagaimana syarah hadits tentang habbatussauda dalam peningkatan imun di masa Covid-19. Tujuan penelitian ini yaitu membahas syarah hadits tentang habbatussauda dalam peningkatan imun di masa Covid-19. Sedangkan pertanyaan terperinci sebagai berikut: 1) Bagaimana teks hadits tentang habbatussauda; 2) Bagaimana kualitas hadits tentang habbatussauda; dan 3) Bagaimana syarah hadits tentang habbatussauda dalam peningkatan imun di masa Covid-19. Tujuan penelitian ini yaitu membahas hadits habbatussauda sebagai salah satu alternatif dalam meningkatkan imun pada masa Covid-19. Terlebih lagi penelitian ini dapat menambah wawasan bagi khalayak ramai agar senantiasa berhati-hati dalam memahami segala sesuatu, khususnya pada penelitian ini bahasannya adalah dunia kesehatan dan juga ilmu hadits.

\section{Metode Penelitian}

Penelitian ini merupakan pendekatan kualitatif melalui studi pustaka (Darmalaksana, 2020b) dengan menerapkan metode takhrij hadits dan syarah 
Jurnal Riset Agama, Volume 1, Nomor 1 (April 2021): 1-14

Muhamad Ikhsan/Habbatussauda dalam Peningkatan Imun di Masa Covid-19

hadits (Darmalaksana, 2020b). Adapun interpretasi digunakan analisis isu kontemporer (Darmalaksana, 2020b).

\section{Hasil dan Pembahasan}

Hasil penelitian dan pembahasan menyajikan beberapa hal berikut ini.

\section{Teks Hadis Habbatussauda}

Berdasarkan penelusuran hadits tentang habbatussauda melalui aplikasi Ensiklopedi Hadits Kitab 9 Imam (Saltanera, 2015), ditemukanlah beberapa hadits yang terkait, akan tetapi yang akan menjadi pembahasan utama pada penelitian ini ialah hadits riwayat al-Bukhari No. 5255 Kitab Pengobatan Bab Habbatussauda dan pada versi Fathul Bari' No. 5687, berikut ini.

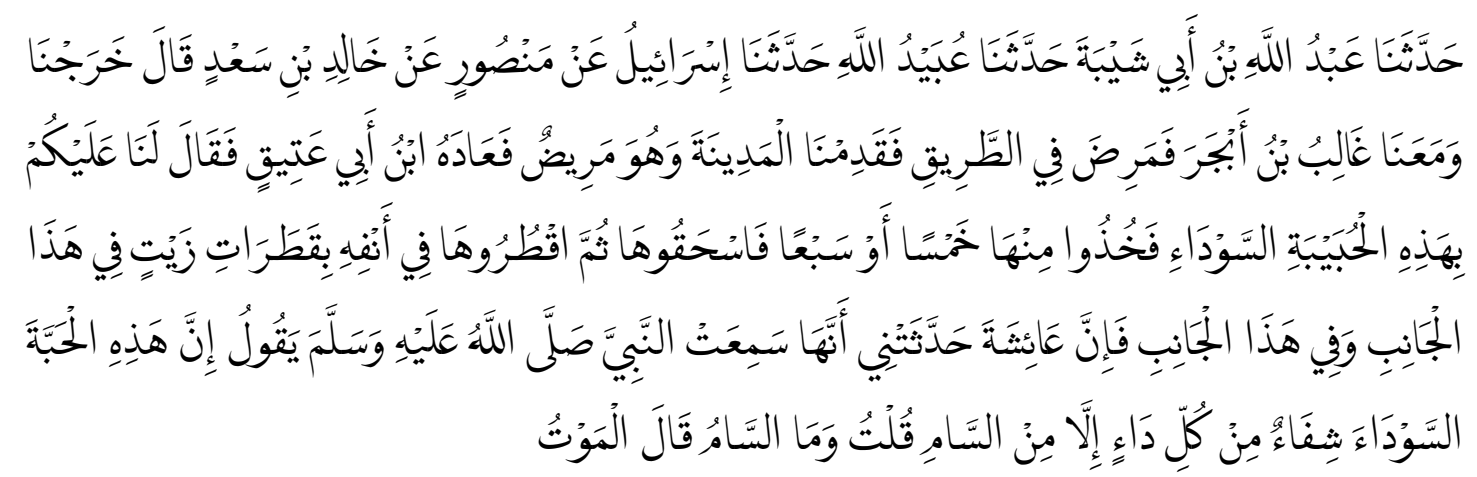

Artinya: Telah menceritakan kepada kami Abdullah bin Abu Syaibah telah menceritakan kepada kami 'Ubaidullah telah menceritakan kepada kami Isra'il dari Manshur dari Khalid bin Sa'd dia berkata; Kami pernah bepergian yang di antaranya terdapat Ghalib bin Abjar, di tengah jalan ia jatuh sakit, ketika sampai di Madinah ia masih menderita sakit, lalu Ibnu Abu 'Atiq menjenguknya dan berkata kepada kami, "Hendaknya kalian memberinya habbatus sauda' (jintan hitam), ambillah lima atau tujuh biji, lalu tumbuklah hingga halus, setelah itu teteskanlah di hidungnya di sertai dengan tetesan minyak sebelah sini dan sebelah sini, karena sesungguhnya Aisyah pernah menceritakan kepadaku bahwa dia mendengar Nabi bersabda, "Sesungguhnya habbatus sauda' ini adalah obat dari segala macam penyakit kecuali saam." Aku bertanya, "Apakah saam itu?" beliau menjawab, "Kematian" [H.R. Al-Bukhari].

\section{Daftar Rawi dan Sanad Hadits Habbatussauda}

Takhrij hadits habbatussauda ditampilkan dalam bentuk tabel berikut ini. 
Jurnal Riset Agama, Volume 1, Nomor 1 (April 2021): 1-14

Muhamad Ikhsan/Habbatussauda dalam Peningkatan Imun di Masa Covid-19

Tabel 1. Daftar Rawi Sanad

\begin{tabular}{|c|c|c|c|c|c|c|c|c|}
\hline \multirow{2}{*}{ No. } & \multirow{2}{*}{$\begin{array}{c}\text { Rawi } \\
\text { Sanad }\end{array}$} & \multicolumn{2}{|c|}{$\begin{array}{l}\text { Lahir/ } \\
\text { Wafat }\end{array}$} & \multirow{2}{*}{ Negeri } & \multirow{2}{*}{ Kuniyah } & \multicolumn{2}{|c|}{ Komentar Ulama } & \multirow{2}{*}{ Kalangan } \\
\hline & & $\mathbf{L}$ & $\mathbf{W}$ & & & - & + & \\
\hline 1 & $\begin{array}{l}\text { Aisyah } \\
\text { binti Abi } \\
\text { Bakar } \\
\text { Ash } \\
\text { Shiddiq }\end{array}$ & & $\begin{array}{l}58 \\
\mathrm{H} .\end{array}$ & Madinah & $\begin{array}{l}\text { Ummu } \\
\text { 'Abdullah }\end{array}$ & & & Shahabat \\
\hline 2 & $\begin{array}{l}\text { Abdullah } \\
\text { bin } \\
\text { Muhamm } \\
\text { ad Abi } \\
\text { 'Atik bin } \\
\text { 'Abdur } \\
\text { Rahman } \\
\text { bin Abi } \\
\text { Bakar }\end{array}$ & & & Madinah & & & $\begin{array}{l}\text { Al-Ajli: } \\
\text { Tsiqah; } \\
\text { Ibnu } \\
\text { Hibban: } \\
\text { Tsiqah; } \\
\text { Adz- } \\
\text { Dzahabi } \\
\text { : Tsiqah }\end{array}$ & $\begin{array}{l}\text { Tabi' in } \\
\text { Middle } \\
\text { Generation }\end{array}$ \\
\hline 3 & $\begin{array}{l}\text { Khalid } \\
\text { bin Sa'ad, } \\
\text { maula } \\
\text { Abi } \\
\text { Mas'ud } \\
\text { al-Badariy }\end{array}$ & & $\begin{array}{c}130 \\
\mathrm{H} .\end{array}$ & Kufah & & & $\begin{array}{l}\text { Ibnu } \\
\text { Hibban: } \\
\text { Disebut } \\
\text { dalam } \\
\text { ats- } \\
\text { Tsiqah; } \\
\text { Yahya } \\
\text { bin } \\
\text { Ma'in: } \\
\text { Tsiqah; } \\
\text { Ibnu } \\
\text { Hajar al- } \\
\text { Asqalan } \\
\text { i: } \\
\text { Tsiqah; } \\
\text { Adz- } \\
\text { Dzahabi } \\
\text { : Tsiqah }\end{array}$ & $\begin{array}{l}\text { Tabi' in Old } \\
\text { Generation }\end{array}$ \\
\hline 4 & $\begin{array}{l}\text { Manshur } \\
\text { bin al- } \\
\text { Mu'tamir }\end{array}$ & & $\begin{array}{l}132 \\
\mathrm{H} .\end{array}$ & Kufah & Abu 'Ittab & & $\begin{array}{l}\text { Al-Ajli: } \\
\text { Tsiqah } \\
\text { tsabat; } \\
\text { Ibnu } \\
\text { Hajar al- } \\
\text { Asqalan } \\
\text { i: Tsiqah } \\
\text { tsabat; }\end{array}$ & $\begin{array}{l}\text { Tabi' in (not } \\
\text { see } \\
\text { Shahabah) }\end{array}$ \\
\hline
\end{tabular}


Jurnal Riset Agama, Volume 1, Nomor 1 (April 2021): 1-14

Muhamad Ikhsan/Habbatussauda dalam Peningkatan Imun di Masa Covid-19

\begin{tabular}{|c|c|c|c|c|c|c|c|}
\hline & & & & & & $\begin{array}{l}\text { Abu } \\
\text { Hatim: } \\
\text { Tsiqah; } \\
\text { Ibnu } \\
\text { Sa'd: } \\
\text { Tsiqah } \\
\text { ma'mun }\end{array}$ & \\
\hline 5 & $\begin{array}{l}\text { Isra'il bin } \\
\text { Yunus bin } \\
\text { Abi Ishaq }\end{array}$ & $\begin{array}{c}160 \\
\mathrm{H} .\end{array}$ & Kufah & $\begin{array}{l}\text { Abu } \\
\text { Yusuf }\end{array}$ & & $\begin{array}{l}\text { Ibnu } \\
\text { Hibban: } \\
\text { Disebut } \\
\text { dalam } \\
\text { ats- } \\
\text { Tsiqah; } \\
\text { Ibnu } \\
\text { Hajar al- } \\
\text { Asqalan } \\
\text { i: Tsiqah }\end{array}$ & $\begin{array}{l}\text { Tabi'ut } \\
\text { Tabi'in Old } \\
\text { Generation }\end{array}$ \\
\hline 6 & $\begin{array}{l}\text { Ubaidulla } \\
\text { h bin } \\
\text { Musa bin } \\
\text { Abi al- } \\
\text { Mukhtar } \\
\text { Badzam }\end{array}$ & $\begin{array}{c}213 \\
\mathrm{H} .\end{array}$ & Kufah & $\begin{array}{l}\text { Abu } \\
\text { Muhamm } \\
\text { ad }\end{array}$ & $\begin{array}{l}\text { Ibnu } \\
\text { Hajar: } \\
\text { Tsiqah } \\
\text { berpaha } \\
\text { m Syiah }\end{array}$ & $\begin{array}{l}\text { Yahya } \\
\text { bin } \\
\text { Ma'in: } \\
\text { Tsiqah; } \\
\text { Abu } \\
\text { Hatim: } \\
\text { Shaduu } \\
\text { q } \\
\text { tsiqah; } \\
\text { Al-Ajli: } \\
\text { Tsiqah; } \\
\text { Ibnu } \\
\text { Adi: } \\
\text { Tsiqah; } \\
\text { Ibnu } \\
\text { Hibban: } \\
\text { Disebut } \\
\text { dalam } \\
\text { ats- } \\
\text { Tsiqah; } \\
\text { Adz- } \\
\text { Dzahabi } \\
\text { :Tsiqah }\end{array}$ & $\begin{array}{l}\text { Tabi'ut } \\
\text { Tabi'in } \\
\text { Ordinary } \\
\text { Generation }\end{array}$ \\
\hline 7 & $\begin{array}{l}\text { Abdullah } \\
\text { bin } \\
\text { Muhamm } \\
\text { ad bin } \\
\text { Abi } \\
\text { Syaibah } \\
\text { Ibrahim }\end{array}$ & $\begin{array}{c}235 \\
\mathrm{H} .\end{array}$ & Kufah & $\begin{array}{l}\text { Abu } \\
\text { Bakar }\end{array}$ & & $\begin{array}{l}\text {-Ahmad } \\
\text { bin } \\
\text { Hambal: } \\
\text { Shaduu } \\
\text { q }\end{array}$ & $\begin{array}{l}\text { Tabi'ul } \\
\text { Atbal Old } \\
\text { Generation }\end{array}$ \\
\hline
\end{tabular}


Jurnal Riset Agama, Volume 1, Nomor 1 (April 2021): 1-14

Muhamad Ikhsan/Habbatussauda dalam Peningkatan Imun di Masa Covid-19

\begin{tabular}{|c|c|c|c|c|c|c|c|}
\hline & $\begin{array}{l}\text { bin } \\
\text { 'Utsman }\end{array}$ & & & & & $\begin{array}{l}\text {-Abu } \\
\text { Hatim: } \\
\text { Tsiqah }\end{array}$ & \\
\hline 8 & $\begin{array}{l}\text { Abu } \\
\text { Abdillah } \\
\text { Muhamm } \\
\text { ad bin } \\
\text { Ismail bin } \\
\text { Ibrahim } \\
\text { bin al- } \\
\text { Mughirah } \\
\text { bin } \\
\text { Bardizbah } \\
\text { al-Ju'fi al- } \\
\text { Bukhari }\end{array}$ & $\begin{array}{c}194 \\
\mathrm{H} .\end{array}$ & $\begin{array}{c}256 \\
\mathrm{H} .\end{array}$ & Bukhara & $\begin{array}{l}\text { Abu } \\
\text { Abdullah }\end{array}$ & $\begin{array}{l}\text { Imam } \\
\text { Hadith }\end{array}$ & Mudawwin \\
\hline
\end{tabular}

Tabel 1 merupakan daftar rawi dan sanad hadits riwayat Imam al-Bukhari No. 5255 Kitab Pengobatan Bab Habbatussauda dan pada versi Fathul Bari' No. 5687 tentang habbatussauda. Pada tabel tersebut terdapat matrik rawisanad, tahun lahir dan wafat, negeri, kuniyah (panggilan), komentar ulama, dan disebutkan pula kalangannya. Hadits ini diriwayatkan oleh 8 (delapan) orang rawi mulai dari mukharrij sampai mudawwin. Hanya 1 (satu) orang rawi yang tidak diketahui tahun lahir dan wafat, yaitu Abdullah bin Muhammad Abi 'Atik bin 'Abdur Rahman bin Abi Bakar. Semua ulama memberikan komentar positif ( $t a^{\prime}$ dil) kecuali penilaian negatif (jarh) terhadap Ubaidullah bin Musa bin Abi al-Mukhtar Badzam yakni disebut tsiqah berpaham Syiah (Saltanera, 2015). Menurut ilmu hadits, rawi terakhir adalah sanad pertama sedangkan rawi pertama ialah sanad terakhir (Darmalaksana, 2021b).

\section{Kualitas Hadits Habbatussauda}

Syarat hadits berkualitas shahih bila sanad bersambung, rawi adil dan dhabit, matan hadits tidak janggal dan tidak cacat (Darmalaksana, 2018). Pada Tabel 1 tampak Ibnu Hajar menilai Ubaidullah bin Musa bin Abi al-Mukhtar Badzam sebagai tsiqah berpemahaman Syiah. Akan tetapi jika dilihat secara keseluruhan ternyata bukan hanya Ubaidullah bin Musa saja periwayat yang tertuduh Syiah di dalam kitab Shahih Bukhari, melainkan ada 12 rawi yang tertuduh Syiah termasuk di dalamnya adalah Ubaidullah bin Musa (Alis, 2017). Ubaidillah bin Musa juga ternyata merupakan seorang periwayat yang terdapat dalam kitab hadits Imam Muslim, Abu Dawud, at-Tirmidzi, an-Nasa'i, dan Ibnu Majah (Alis, 2017). Ibnu Hajar al-Asqalani mengomentari Ubaidillah bin Musa sebagai seorang yang Tasyayyu' (Alis, 2017). Tasyayyu' jika mengikuti istilah yang digunakan oleh Ibnu Hajar al-Asqalani berarti mencintai Saidina 
Jurnal Riset Agama, Volume 1, Nomor 1 (April 2021): 1-14

Muhamad Ikhsan/Habbatussauda dalam Peningkatan Imun di Masa Covid-19

'Ali dan mengutamakannya dibanding semua shahabat lain (Alis, 2017). Lalu, lafaz-lafaz jarh seperti: Syiah, tasyayyu', rafadh, dan ghulat seperti disebutkan pada kitab Tahzib al-Kamal karya al-Mizzi bahwa istilah-istilah itu hanya sebatas melebihkan Saidina 'Ali daripada shahabat-shahabat lain, namun tidak sampai mengkafirkan para shahabat lainnya (Alis, 2017). Selanjutnya para perawi yang tertuduh Syiah pada kitab Shahih al-Bukhari hanya meriwayatkan dalam permasalahan akhlak dan fikih bukanlah dalam masalah hukum dan akidah (Alis, 2017). Lalu perbedaan lainnya lagi ialah, Syiah pada zaman dahulu berbeda dengan Syiah pada zaman sekarang, perbedaannya hanyalah dari aspek politik dan kecintaan kepada Ahlulbait lebih tinggi dibandingkan shahabat lainnya dan hal itu tidaklah merusak kualitas hadits yang diriwayatkan oleh para perawi yang berpaham Syiah selagi mereka masih ada syarat yang baik dalam meriwayatkan hadits (Alis, 2017). Senada dengan pandangan mayoritas ahli hadits "apabila hadits atau riwayat yang disebutkan oleh Imam Muslim ataupun Imam al-Bukhari dalam kitab Shahihnya melalui jalur para perawi mubtadi' (pelaku bid'ah) walaupun seorang perawi Syiah maka diharapkan tidak gegabah untuk menyudutkannya karena banyak pertimbangan yang diyakini oleh kedua mudawwin tersebut, sehingga periwayatannya dari jalur para periwayat mubtadi' walaupun Syiah tidaklah mengurangi kesahihan hadits bahkan tidak ada unsur propaganda terhadap ajaran sekte para periwayat tersebut dikarenakan sifat kejujuran yang dimiliki oleh para periwayat mubtadi' tersebut" (Tujang, 2017).

Persambungan sanad merupakan salah satu dari beberapa unsur yang sangat penting untuk menentukan keshahihan sanad hadits (Firdaus, 2015). Syarat sanad bersambung adalah bertemu (liqa') antara guru yaitu penyampai hadits dan murid yakni penerima hadits (Darmalaksana, 2018, 2020c, 2021b). Antara guru dan murid dapat dikatakan bertemu apabila sezaman dan atau mereka berada di satu wilayah, yang mana hal itu dapat dilihat dari tahun lahir dan wafat para periwayat (Darmalaksana, 2018, 2020c, 2021b). Apabila para periwayat tidak diketahui tahun lahir dan wafat, maka para rawi dapat diasumsikan rata-rata berusia kurang lebih 90 tahun (Darmalaksana, 2018, 2020c, 2021b, 2021a). Berdasarkan kaidah tersebut, meskipun pada Tabel 1 beberapa rawi tidak diketahui tahun lahir dan wafat, maka para rawi diperkirakan bertemu antara guru dan murid. Dengan kata lain sanad hadits pada Tabel 1 dapat dikatakan bersambung atau hadits yang memiliki sanad bersambung bisa diistilahkan dengan muttashil (Firdaus, 2015).

Selain dari sisi rawi dan sanad, kualitas hadits juga ditinjau dari segi matannya dengan syarat terhindar dari syadz dan 'illat (Chandra \& M, 2016). Dari sisi matan, teks hadits tentang habbatussauda ini tidak janggal dalam arti 
Jurnal Riset Agama, Volume 1, Nomor 1 (April 2021): 1-14

Muhamad Ikhsan/Habbatussauda dalam Peningkatan Imun di Masa Covid-19

struktur kalimat tersusun sistematis dan logis, serta tidak bertolak belakang dengan al-Qur'an dan juga hadits lain. Dengan demikian dari paparan yang telah dijelaskan, dapat diambil kesimpulan bahwa hadits ini dapat diterima sebagai hadits shahih. Terlebih lagi hadits ini terdapat dalam kitab Shahih alBukhari, yang kriteria beliau merupakan yang sangat ketat dalam pemilihan hadits untuk diambil ke dalam kitabnya (al-Jami' al-Shahih), bahkan Imam alBukhari jelas berkata "Ma adkhaltu fi al-Jami' Illa Ma Shahha" (Muhsin, 2016).

\section{Syarah Hadits Habbatussauda}

Kata syarah yang diindikasikan kepada hadits Nabi berarti merupakan suatu upaya untuk menjelaskan atau mengungkapkan makna yang terkandung pada teks hadits (Muhtador, 2016). Syarah hadits beguna untuk memberikan pemahaman bagi pengamal hadits tersebut (Darmalaksana, 2021b). Hadits dapat diamalkan ( $m a^{\prime} m u l$ ) apabila hadits tersebut diterima (maqbul) melalui takhrij (Darmalaksana, 2021b). Seperti telah diuraikan status hadits riwayat Imam al-Bukhari No. 5255 berkualitas shahih.

Disebutkan dalam hadits riwayat Imam al-Bukhari No. 5255 bahwa habbatussauda merupakan obat segala penyakit kecuali as-saam (kematian), namun ternyata maksudnya bisa saja bukan habbatussauda murni melainkan ada campuran bahan lain juga (Al-Asqalani, 2002). Seperti disebutkan pada riwayat al-A'yun yang dikutip al-Ismaili yang diperjelas oleh riwayat Ibnu Abi Syaibah, kemudian ditemukan pula dari hadits Buraidah yang dinukil dari alMustaghfiri dalam kitab ath-Thibb melalui jalur Hassam dari Ubaidillah bin Buraidah dari Nabi Saw. bahwa diperintahkan untuk mengambil dua puluh satu biji habbatussauda dan letakkan pada selembar kain lalu rendam dalam air satu malam, lalu singkatnya pada hari-hari setelahnya diteteskan pada lubang hidung (Al-Asqalani, 2002). Menurut Syaikh Utsaimin (n.d.) pernyataan “obat segala macam penyakit kecuali as-saam" adalah bersifat universal karena hakikatnya kematian tidak dapat dipengaruhi oleh segala macam obat.

Habbatussauda adalah sejenis tumbuh-tumbuhan yang dikenal dengan berbagai jenis nama di antaranya jintan hitam, black cumin, nigella sativa, corek out, kalonji, natural seed, black caraway (M.Dalil, 2017), dan mungkin masih banyak lagi. Tumbuhan ini memiliki banyak manfaat untuk mengatasi berbagai masalah kesehatan dan kecantikan (M.Dalil, 2017).

Seperti disebutkan oleh Maharani Amanulloh dan Ester Krisdayanti (2019) jintan hitam memiliki manfaat farmakologis di antaranya sebagai antioksidan, antidiabetes, antialergi, antiinflamasi, dan sebagai imunomodulator, sehingga jintan hitam sering digunakan sebagai obat herbal. Telah terbukti bahwa hasil percobaan penggunaan nigella sativa (habbatussauda) 
Jurnal Riset Agama, Volume 1, Nomor 1 (April 2021): 1-14

Muhamad Ikhsan/Habbatussauda dalam Peningkatan Imun di Masa Covid-19

terhadap orang yang memiliki penyakit osteoarthritis (penyakit radang sendi) dengan hasil berkurangnya rasa nyeri yang diderita oleh para pemilik penyakit radang sendi tersebut (Widjaja, 2020).

Seperti diketahui bahwa Covid-19 merupakan virus yang menyerang sistem pernapasan serta juga akan mudah menginfeksi seseorang yang memiliki sistem imun yang rendah (Amalia et al., 2020). Virus ini juga lebih rentan menginfeksi orang yang memiliki komorbit seperti: diabetes, hyperglycemia, cardiovascular disorder, hypertension, serta juga penyakit-penyakit autoimmune (Islam et al., 2021). Berdasarkan hasil penelitian, diuraikan bahwa, nigella sativa seed dengan kandungan-kandungan utama di dalamnya seperti thymoquinone, nigellidine, dan a-hederin bermanfaat untuk: 1) Meningkatkan respon imun, 2) Mengaktifkan autophagy, 3) Menurunkan inflamasi, 4) Menurunkan oxidative stress, dan 5) Bermanfaat juga menurunkan comorbidities pemicu diabetes, hyperglycemia, cardiovascular disease, paediatric multisystem inflammatory syndrome, kawasaki like disease, darah tinggi, dan bacterial coinfection (Islam et al., 2021).

Status hadits riwayat Imam al-Bukhari No. 5255 berkualitas shahih, baik sanad maupun matan. Dengan demikian hadits ini maqbul dan ma'mul bih bagi amalan Islam (Darmalaksana, 2021b). Walaupun demikian, penggunaan habbatussauda juga meski mengikuti aturan pakai yang telah ditetapkan oleh para ahli terkait dengan obat-obatan, yakni para tenaga medis khususnya para ahli di bidang kesehatan.

\section{Kesimpulan}

Sebelum adanya virus Covid-19 dan sebelum berkembang pesatnyanya ilmu pengetahuan khususnya ilmu kedokteran seperti saat ini, telah seribu tahun lebih Rasulullah Saw. memberitahukan bahwa di dalam habbatussauda terdapat obat untuk berbagai macam penyakit, sehingga kita perlu meyakininya bahwa memang hebatlah informasi dan segala sesuatu yang berasal dari Nabi, walaupun tidak bisa dimaknai seutuhnya bahwa obat untuk segala macam penyakit mutlak. Dari sisi ilmu hadits, hadits yang telah dipaparkan di awal pembahasan yaitu H.R. al-Bukhari No. 5255 jelaslah dapat diterima dan otomatis $m a^{\prime} m u l$ bih bagi amalan muslim dikarenakan hadits ini jelas berada di dalam kitab Shahih al-Bukhari dan juga seperti telah dipaparkan bahwa komentar negatif terhadap salah satu perawinya dapatlah diterima karena tidak merusak kualias hadits. Adapun untuk peningkatan imunitas seseorang habbatussauda dapatlah digunakan pada kebanyakan orang tanpa terkecuali orang dengan kondisi tertentu, tetapi untuk memaknai benarbenar obat bagi segala penyakit kuranglah tepat, sehingga pada dasarnya 
Jurnal Riset Agama, Volume 1, Nomor 1 (April 2021): 1-14

Muhamad Ikhsan/Habbatussauda dalam Peningkatan Imun di Masa Covid-19

ketika sakit berobatlah dengan obat yang sesuai dengan macam penyakitnya, bukan hanya dengan habbatussauda. Diharapkan penelitian ini memiliki manfaat bagi khazanah pengetahuan Islam, sehingga diharapkan bagi para peneliti khususnya di bidang kesehatan untuk mengkaji ulang bagaimana langkah yang terbaik dalam menanggulangi Covid-19 serta juga dalam pengolahan obat-obat tradisional seperti habbatussauda yang telah disinggung pada penelitian ini. Penelitian ini juga memiliki keterbatasan baik dalam penguasaan ilmu hadits maupun dalam bidang ilmu kesehatan sehingga dibutuhkan penelitian lebih lanjut, yang mungkin bisa membantah atau mendukung penelitian ini.

\section{Daftar Pustaka}

Al-'Utsaimin, S. M. bin S. (n.d.). Syarah Shahih al-Bukhari. Darus Sunnah.

Al-Asqalani, I. H. (2002). Fathul Baari: Penjelasan Kitab Shahih al-Bukhari. In 28. Pustaka Azzam.

Alis, M. K. Bin. (2017). Perawi yang Tertuduh Syiah dalam Shahih al-Bukhari. UIN Suska RIau.

Amalia, L., Irwan, \& Hiola, F. (2020). Analisis Gejala Klinis dan Peningkatan Kekebalan Tubuh Untuk Mencegah Penyakit Covid-19. Jambura Journal of Health Sciences and Research, 2(2). https:/ / doi.org/10.35971/jjhsr.v2i2.6134

Amanulloh, M., \& Krisdayanti, E. (2019). Jintan Hitam Sebagai Imunomodulator dan Anti Inflamasi pada Pasien Asma. Jurnal Penelitian Perawat Profesional, 1(1), 115-120. https://doi.org/doi.org/10.37287/jppp.v1i1.32

Arofi, Z. (2021). View of Optimis di Tengah Pandemi: Cara Rasulullah Menyelesaikan Masalah Pandemi. https://journal.unimma.ac.id/index.php/ce/article/view/4417/2032

Bakar Adanan, A. (2020). Kitab Shahih Al-Bukhari. Ihya Al-Arabiyah: Jurnal Pendidikan Bahasa Dan Sastra Arab, 6, 148-162.

Chandra, A. F., \& M, B. (2016). Kriteria Ke-shahih-an Hadis Menurut alKhathib al-Baghdadi Dalam Kitab al-Kifayah fi 'Ilm al-Riwayah. Jurnal Ushuluddin Uin Sultan Syarif Kasim Riau, 24(2), 162-174. https:/ / doi.org/http:/ / dx.doi.org/10.24014/jush.v24i2.1725

Darmalaksana, W. (2018). Paradigma Pemikiran Hadis. Jurnal Aqidah Dan Filsafat Islam, 95-106. http:/ / digilib.uinsgd.ac.id/id/eprint/8585

Darmalaksana, W. (2020a). Formula Penelitian Pengalaman Kelas Menulis. Jurnal Kelas Menulis UIN Sunan Gunung Djati Bandung.

Darmalaksana, W. (2020b). Metode Penelitian Kualitatif Studi Pustaka dan Studi Lapangan. Pre-Print Digital Library UIN Sunan Gunung Djati 
Jurnal Riset Agama, Volume 1, Nomor 1 (April 2021): 1-14

Muhamad Ikhsan/Habbatussauda dalam Peningkatan Imun di Masa Covid-19

Bandung, 1-6.

Darmalaksana, W. (2020c). Prosiding Proses Bisnis Validitas Hadis untuk Perancangan Aplikasi Metode Tahrij. Jurnal Ushuluddin UIN Sunan Gunung Djati Bandung, 1, 1-7.

Darmalaksana, W. (2021a). Herbal Tumbuhan Senna dalam Pengobatan Infeksi Covid-19: Studi Takhrij dan Syarah Hadis. Pre-Print Kelas Menulis UIN Sunan Gunung Djati Bandung, 19, 1-11. http://digilib.uinsgd.ac.id/id/eprint/41967\%0A

Darmalaksana, W. (2021b). Kosmetik Halal sebagai Lifestyle untuk Kesehatan: Studi Takhrij dan Syarah Hadis.

Firdaus. (2015). Penelitian Persambungan Sanad Hadis. Al-Qalam Jurnal Kajian Islam $\mathcal{E}$ Pendidikan, 7(1), 67-80. https://doi.org/10.47435/alqalam.v7i1.179

Halim, A. A., Kamel, A., Ii, M., Zakaria, N., Mohd, W., Iv, S., Najihuddin, S., Hassan, S., Salaeh, A., \& Hoque, M. (2020). Habbatus Sauda'. https:/ / oarep.usim.edu.my/jspui/bitstream/123456789/6852/1/Wabak Covid-19 dan Hubungannya Dengan Hadith Kelebihan Habbatus Sauda'.pdf

Islam, M. N., Hossain, K. S., Ferdous, J., Rahman, M., \& Uddin, J. (2021). Revisiting pharmacological potentials of Nigella sativa seed : A promising option for COVID-19 prevention and cure. National Research Foundation of Korea, 35(3), 1329-1344. https:/ / doi.org/10.1002/ ptr.6895

M.Dalil, F. Y. (2017). Hadis-hadis Tentang Farmasi; Sebuah Kajian Integratif Dalam Memahami Hadis Rasulullah. Proceeding IAIN Batusangkar, 1(1), 309-326.

https://ojs.iainbatusangkar.ac.id/ojs/index.php/proceedings/article/vi ew $/ 551$

Muhsin, M. (2016). Metode Bukhari dalam al-Jami' al-Shahih: Tela'ah atas Tashhih dan Tadh'if menurut Bukhari. Jurnal Holistic Al-Hadis, 02(02), 279291. https://doi.org/http:/ / dx.doi.org/10.32678/holistic.v2i2.953

Muhtador, M. (2016). Sejarah Perkembangan Metode dan Pendekatan Syarah Hadis. Riwayah: Jurnal Studi Hadis, 2(2), 259-272. https:/ / doi.org/10.21043/riwayah.v2i2.3130

Rahman, F. (1974). Ikhtisar Mushthalahul Hadits. Al-Ma'arif.

S. Puyu, D. (2012). Metode Takhrij Al-Hadis melalui Kosa Kata, Tematik dan CD Hadis (Z. Alwi (ed.)). Alauddin University Press.

Saltanera. (2015). Ensiklopedi Hadits Kitab 9 Imam. Lembaga Ilmu Dan Dakwah Publikasi Sarana Keagamaan, Lidwa Pusaka. https://store.lidwa.com/get/ 
Jurnal Riset Agama, Volume 1, Nomor 1 (April 2021): 1-14

Muhamad Ikhsan/Habbatussauda dalam Peningkatan Imun di Masa Covid-19

Sumarmi, S. (2020). Kerja Harmoni Zat Gizi dalam Meningkatkan Imunitas Tubuh Terhadap Covid-19: Mini Review. Amerta Nutrition, 4(3), 250. https://doi.org/10.20473/amnt.v4i3.2020.250-256

Tujang, B. (2017). Intensitas Pengaruh Periwayatan Perawi Propagandis Tasyayyu', Syi' ah dan Rafidah Terhadap Ajaran Syi'ah atau Sunni (Studi Analisis Terhadap Riwayat Perawi-perawi Dalam Shahih Muslim). AlMajaalis: Jurnal Dirasat Islamiyah, 5(1), 1-56. https://doi.org/https://doi.org/10.37397/almajaalis.v5i1.85

Widjaja, C. H. (2020). Literatur Riview Manfaat Jintan Hitam ( Nigella sativa ) sebagai Antiinflamasi dan Pereda Nyeri pada Osteoartritis ( OA ). Jurnal Ilmiah Kesehatan Sandi Husada, 9(2), 902-907. https:/ / doi.org/10.35816/jiskh.v12i2.433

Yuliana, Y. (2020). Corona virus diseases (Covid-19): Sebuah tinjauan literatur. Wellness And Healthy Magazine, 2(1), 187-192. https:/ / doi.org/10.30604/well.95212020 